\title{
Rastros de sobrevivência no documentário brasileiro pós-64
}

\author{
Augusto Sarmento-Pantoja ${ }^{1}$
}

${ }^{1}$ Doutorando pela Universidade Estadual de Campinas (UNICAMP). Professor Assistente da Universidade Federal do Pará. Líder do Grupo de Pesquisa Estéticas, Performances e Hibridismos (ESPERHI), Coordena o projeto Literatura e Cinema de Resistência: performances na tragédia da Antiguidade à Contemporneidade.

Organizador dos livros Memória e Resistência (2012), Literatura e Cinema de Resistência (2013), Vertigens do Olhar: estudos de literatura vernácula (2013), Estudos de Literatura e Resistência (2014). e-mail: augustos@ufpa.br; a.sarmentopantoja@gmail.com 


\section{Resumo}

Este estudo discute de que modo podemos conceber a sobrevivência após experiências traumáticas vividas por militantes políticos que lutaram contra a ditadura civil-militar brasileira pós1964 e estiveram literalmente dentro do olho do furacão. A sobrevivência em si traz questões ambíguas em relação à construção dos testemunhos e, por isso, devem ser estudadas em seus pormenores. Utilizaremos para nossas análises dois documentários produzidos após a abertura política no Brasil, o primeiro de 1989, Que bom te ver viva, de Lúcia Murat, e o segundo de 2003,No olho do furacão, de Renato Tapajós e Tony Venturi. Entre aspectos destacados temos as formas estéticas dos filmes e a presença do narrador/personagem/testemunho.

Palavras-chave: sobrevivência; testemunho; documentário; ditadura.

\section{Abstract}

This paper discusses how we can conceive of survival after traumatic experiences of political activists who fought against the Brazilian civil-military post-1964 dictatorship and were literally in the eye of the hurricane. Survival itself brings ambiguous issues regarding the construction of the witnesses and, therefore, should be studied in its details. For our analysis we use two documentaries produced after the political opening in Brazil, the first one from 1989, Lucia Murat's Que bom te ver viva, and the second one from 2003, Renato Tapajós and Tony Venturi's No olho do furacão. Among the highlighted issues, there are the aesthetic forms of the films and the presence of the narrator / character / witness.

Keywords: survival; testimony; documentary; dictatorship. 


\title{
Quando a sobrevivência é resiliência
}

\begin{abstract}
Warburg dizia a seu próprio respeito que ele menos fora feito para existir do que para "persistir [eu diria insistir] como uma bela lembrança". É bem esse o sentido da palavra Nachleben, esse termo do "pós-viver": um ser do passado que não para de sobreviver. Num dado momento, seu retorno em nossa memória torna-se a própria urgência, a urgência anacrônica do que Nietzsche chamou de inatual ou intempestivo. $^{2}$
\end{abstract}

Georges Didi-Huberman

Pode parecer incompreensível, à primeira vista, dizer que sobreviver não estava nos planos da maioria dos militantes de esquerda que se envolveram com a luta armada no Brasil. Entretanto, esta proposição verbera os discursos de diversos militantes, no sentido de que estavam preparados para tudo, menos para "a terceira hipótese, [a de] que a gente poderia sobreviver e ser derrotado. Para essa eu não me preparei ${ }^{3}$. Sobreviver, não seria simplesmente um infinitivo latino supervivĕre, ou um simples "continuar a viver depois de outra pessoa ter morrido" ou mesmos "subsistir depois da perda ou ruína de alguém ou alguma coisa"4. Georges Didi-Huberman quando analisa a obra de Warburg deixa clara a urgência da sobrevivência. O passado traumático faz com que o tempo seja profundamente relativo, pois não temos como mensurar nem quando, nem onde e nem como o sobrevivente conseguirá narrar, seja o que for ou como for. Mesmo que a narrativa do sobrevivente esteja fora do tempo histórico, ela estará sempre em um tempo presente para o sobrevivente que não vê a hora de se sentir em condições de

\footnotetext{
${ }^{2}$ DIDI-HUBERMAN, 2013, p. 29

${ }^{3}$ Testemunho de Carlos Eugênio (Clemente), líder da ALN e sucessor de Carlos Marighella e Toledo. Único líder da ALN que não foi preso pela ditadura brasileira. In. TAPAJÓS, Renato \& VENTURI, Tony. No olho do Furacão. Documentário. Brasil. Cores. Português, 2003.

${ }^{4}$ Acepções do verbete "sobreviver" retiradas do Dicionário Eletrônico Michaelis (Português). Disponível em: http://michaelis.uol.com.br/moderno/portugues/index.php?lingua=portuguesportugues\&palavra=sobreviver
} 
narrar, sem sucumbir. Narrar sem sucumbir é o desejo de homens e mulheres que testemunham suas experiências durante a ditadura civil-militar no Brasil. Esses testemunhos se aproximam pelo fato de fazerem parte de um grupo que perdeu o direito à vida e passaram a uma condição de indivíduos amotinados em uma "sobre vivência".

A sobre vida que toma conta dos testemunhos pode ser compreendida tal qual nos apresenta Beatriz Bergieri: "Meu corpo está preso, minha alma não" ${ }^{6}$. A separação entre corpo e alma revela a utopia revolucionária que se mantém mesmo diante da prisão dos corpos sofridos e sorvidos pela tortura. Mesmo passados muitos anos, as experiências catastróficas ficam latentes em suas memórias, impossibilitando a sobreviver tão simplesmente. Encontramos uma recorrência nessas narrativas, uma forte insatisfação por terem sidos esquecidos em suas sobrevidas, ou melhor, na vida que Ihes sobrou, pois a vida de suas existências ficou para traz. Mas o presente the bate à porta e lhe diz que para sobreviver é preciso esquecer o passado. Mas será que isso é possível?

Primo Levi já refletia sobre isso em É isto um homem? Para ele todos que passaram pelo Lager sabem de onde vêm, já que "as lembranças do mundo de fora povoam nossos sonhos e nossas vigílias; percebemos com assombro que não esquecemos nada; cada lembrança evocada renasce à nossa frente, dolorosamente nítida" ${ }^{7}$. Quando pensamos em sobrevivência diante do testemunho, o que acaba por sobressair é o fato de não haver possibilidade de saber onde cada um desses sobreviventes irá parar. No caso da Shoah, o testemunho contempla um caminho que leva a um retorno inconsciente ao passado aterrorizador, já que "talvez sobrevivamos às doenças e escapemos às seleções, talvez aguentemos o trabalho e a fome que nos consomem, mas, e depois?" Sabemos que o sobrevivente pode ficar longe das blasfêmias e das

\footnotetext{
${ }^{5}$ CORNELSEN, 2011, p. 13

${ }^{6}$ TELES; RIDENTI; IOKOI, 2010, p.104.

${ }^{7}$ LEVI, 1998, p. 54

${ }^{8}$ Idem
} 
pancadas, mas até quando? Já que o horror está "dentro de nós mesmos" 9 . Certamente o sobrevivente voltará muitas vezes, pois não será capaz de esquecer, não por ressentimento, tão simplesmente, mas pela impossibilidade de resilir. Se pensarmos que o conceito resiliência está atrelado a ideia de esquecimento, como destaca Boris Cyrulnik compreendemos tão bem o embate realizado entre os sobrevivente e sua tentativas de sobrevida.

Se esses homens e mulheres não estavam preparados para a sobrevivência como fazer após sobreviver? Muitos serão os caminhos percorridos pelos sobreviventes, mas de certa forma, todos estão associados à necessidade de narrar o trauma, mesmo quando isso é impossível. Nos filmes que analisaremos consideramos que os testemunhos ali presentes representam a figura do narrador/personagem/testemunho. Tomemos as considerações de Paul Ricoeur sobre a diferença entre ponto de vista e voz narrativa:

O mundo contado é o mundo do personagem e é contado pelo narrador. Ora a noção de personagem está solidamente ancorada na teoria da narrativa, na medida em que a narrativa não poderia ser uma mimese de ação sem ser igualmente uma mimese de seres agentes; ora seres agentes são, no sentido amplo que a semântica da ação confere à noção de agente, seres que pensam e que sentem; melhor, seres capazes de falar seus pensamentos, seus sentimentos e suas ações. A partir de então é possível deslocar a noção de mimese de ação para o personagem e do personagem para o discurso do personagem. ${ }^{10}$

Desse modo passamos a compreender uma simbiose entre narrador, personagem e testemunho, pois as narrativas dos documentários são construídas por testemunhos de sobreviventes que, no momento de construção de seu testemunho, são narradores de suas experiências; ao mesmo tempo personagens de si, que foram construídas para suportar a dificuldade de construir o testemunho. Assim temos narradores e narradoras que tomam a voz narrativa para testemunhar e contam o que a personagem sobrevivente e militante consegue narrar. Assim, as narrativas dos sobreviventes se aproximam do que

\footnotetext{
${ }^{9}$ Op cit. p. 55

${ }^{10}$ RICOEUR, 1995, p. $147-148$
} 
Boris Cyrulnik conceitua em O murmúrio dos fantasmas, de narrativas resilientes:

Experimentamos um alívio e até certo orgulho quando superamos a dificuldade, enquanto que a confusão é a regra após um traumatismo. O torpor de nossa representação torna o mundo incompreensível porque a obnubilação nos fixa em um detalhe que significa a morte iminente e nos fascina tanto que obscurece o resto do mundo. ${ }^{11}$

Há nesta descrição uma agonia psíquica que acomete o indivíduo traumatizado, associado à construção de mecanismos de defesa para com a memória traumática. Para Cyrulnik essas defesas são "chamas tênues de existência" capazes de promover a sobrevivência diante do trauma ou simplesmente a resiliência. Esses mecanismos de defesa já são cintilados por Sigmund Freud ao definir trauma, pois o trauma está diretamente ligado a uma ruptura, que constrói uma espécie de barreira responsável por impedir que outros estímulos possam influenciar o indivíduo traumatizado, já que "um trauma externo está destinado a provocar um distúrbio em grande escala no funcionamento da energia do organismo e a colocar em movimento todas as medidas defensivas possiveis." ${ }^{12}$

As defesas propostas por Freud fazem com que associemos o trauma a sua irrepresentabilidade, uma vez que as defesas podem afastar completamente o narrador do fato traumático, impossibilitando sua narração, porém permanecendo nele a necessidade de sobreviver mesmo diante do trauma, o que desencadeia o fortuito desenvolvimento das narrativas da memória traumática. Marcadas por um trabalho memorialístico com inúmeros mecanismos de defesa que garantam uma representabilidade, não do trauma, mas de algo que se aproxime a ele, o que é possível, o que é resiliente. Tal narrativa será não só necessária, por possibilitar a memória da experiência extrema, mesmo que sempre de modo estilhaçado, mas, sobretudo, por permitir a sobrevivência desse narrador. O trauma, assim, gera um estado de resiliência da memória, fazendo com que o indivíduo permaneça em

\footnotetext{
${ }^{11}$ CYRULNIK , 2005, p. 41

${ }^{12}$ FREUD, v.18, 1996, p. 19
} 
constante estado de tensão, pois para ele o trauma sofrido envolve continuamente "a ideia de perigo mortal, de uma ameaça à vida"13. Por isso acreditamos que a resiliência nesse sentido não faz com que o trauma seja esquecido ou superado, pelo contrário, quando o narrador consegue manter-se diante da experiência rememorada ele resile, sem esquecer, mas suportar. É por isso que preferimos falar na capacidade de suportar e não superar, já que não há nada para superar, pois o sobrevivente não é culpado por sofrer.

As narrativas ligadas às experiências traumáticas como a Shoah, no início do século XX, e as ditaduras na América Latina, na segunda metade do século XX, representam bem esses espaços de construção de narrativas da memória traumática e a realização de seus testemunhos, a evidência de sua resiliência. Marcadas por diversas estratégias de defesa buscando dar ressonâncias à ferida traumática e permitir a construção de narrativas de tais experiências-limite. Entre as estratégias podemos destacar o esquecimento e a falsa memória. Elas devem ser entendidas, a partir das postulações de Freud quando analisa a existência do esquecimento de impressões e o de intenções, como aquelas que enquanto "esquecimento de impressões pode ser acompanhado por falsas recordações, que, quando merecem crédito, são designadas de ilusões de memória [Erinnerungstäuschung]"14. Esquecer e lembrar ou esquecer-se de lembrar para lembrar-se de esquecer, essas são situações que pungem quando falamos de sobrevivência. As reflexões de Primo Levi marcam o caminho da difícil tarefa de lembrar, ou melhor, de continuar lembrando quando a lembrança é tão aterradora, por isso Levi destaca que não existe um testemunho "melhor" ou "pior" que o outro, já que não temos como diferenciar uma experiência de outra, já que cada uma tem suas particularidades e merecem ser analisadas, seja por valores positivos ou negativos. "Desejaríamos chamar a atenção sobre o fato de que o Campo foi também (e marcadamente) uma notável experiência biológica e

\footnotetext{
${ }^{13}$ FREUD, v. 3, 1996 , p. 16

${ }^{14}$ FREUD, v. 6, 1996:98
} 
social"15.

Tais experiências descritas por Levi potencializam um interessante debate sobre a natureza do testemunho, uma vez que o mesmo, além de estar contido na esfera da experiência humana, acaba por pautar as experiências de uma sociedade, de uma coletividade, de um grupo, saindo da esfera do drama individual, passando à esfera dos dramas coletivos. Com isso concordamos com Valéria de Marco quando esta analisa que o testemunho "reconstitui a história de um ou mais sujeitos escolhidos pela relevância que eles possam ter em um contexto social”16. A relevância do narrador testemunhal pode ser construída na medida em que conseguimos garantir um espaço para essas memórias, como afirma Beatriz Sarlo, já que a memória não está fundada somente no indivíduo tal qual o testemunho, ela é "um bem comum, um dever (como se disse no caso europeu) e uma necessidade jurídica, moral e política"17, como no caso latinoamericano. Isso por que fica notória a falta de critério e cuidado para com a análise de narrações de vítimas desses grandes descalabros ditatoriais. Por isso é preciso compreender que "se o núcleo de sua verdade deve ser inquestionável, também seu discurso deveria ser protegido do ceticismo e da crítica. A confiança nos testemunhos das vítimas é necessária para a instalação de regimes democráticos e o enraizamento de um princípio de reparação e justiça" ${ }^{\text {"18. Pois }}$ bem, esses discursos testemunhais, sejam quais forem, são discursos e não deveriam ficar confinados numa cristalização inabordável. Sobretudo porque, em paralelo e construindo sentidos com os testemunhos sobre os crimes das ditaduras, emergem outros fios de narrações que não estão protegidas pela mesma intangibilidade nem pelo direito dos que sofreram.

\footnotetext{
${ }^{15}$ LEVI, 1998 , p. 88

${ }^{16}$ DE MARCO, 2004, p. 50

17 SARLO, 2007, p. 47

${ }^{18}$ SARLO, 2007, p. 47
} 


\section{A sobrevivência no documentário}

Foram 21 anos, amargados pelo Brasil, de ditadura civil-militar que massacrou homens e mulheres combatentes desse regime cruel e desumano. Com a instalação do governo ditatorial, veio um estado de guerra e um forte esquema de repressão dimensionado pela tarefa militar de destituir, nos porões do DOI/CODI, o direito de sobreviver dos sobreviventes. Isso porque os órgãos de repressão foram extremamente eficazes na tarefa de retirar a dignidade daqueles homens e mulheres e deixar marcas indeléveis no corpo, na alma e, principalmente, nas mentes dos sobreviventes.

A recuperação dos testemunhos de militantes políticos que combateram a ditadura civil-militar no Brasil utilizou-se de um recurso bastante eficaz, o documentário. Estratégia que mistura documento, criação e ficção na tentativa de construir espaços de legitimação do testemunho. É o que ocorre com os documentários Que bom te ver viva (QBTVV), de Lúcia Murat, e No olho do furacão (NOF), de Renato Tapajós e Toni Venturi, que expressam perfeitamente o conflito pela angústia da sobrevivência, em um diálogo indireto com o espectador. Os filmes expõem uma perspectiva construída a partir dos depoimentos das personagens, fragmentos de histórias que se convergem em pontos comuns, expõem fatos reais organizados para que de alguma forma se estabeleça um enredo narrativo, conforme compreende Soares ao definir o gênero documentário:

Documentário é também resultado de um processo criativo do cineasta marcado por várias etapas de seleção, comandadas por escolhas subjetivas desse realizador. Essas escolhas orientam uma série de recortes, entre concepção da ideia e a edição final do filme, que marcam a apropriação do real por uma consciência subjetiva. ${ }^{19}$

A apreensão da realidade histórica da ditadura civil-militar brasileira sob o olhar e a narração dos sobreviventes que foram perseguidos, presos e torturados, constrói o enredo dos dois documentários compostos por 12 entrevistados que se apresentam como verdadeiros narradores/personagens/testemunhas de suas

${ }^{19}$ SOARES, 2007, p. 20 
próprias histórias e das histórias de outros. Essas testemunhas serão responsáveis por narrar para sobreviver e sobreviver para narrar, quase simultaneamente, como destaca Seligmann-Silva:

O testemunho como uma atividade elementar, no sentido de que dela depende da sobrevida daquele que volta do Lager (campo de concentração) ou de outra situação radical de violência que implica esta necessidade, ou seja, que desencadeia esta carência absoluta de narrar. Levi (...) coloca as expressões "aos outros" e "os outros" entre aspas. Este destaque indica tanto o sentimento de que entre o sobrevivente e "os outros" existia uma barreira, uma carapaça, que isolava aquele da vivência com seus demais companheiros de humanidade, como também a consequente dificuldade prevista desta cena narrativa. ${ }^{20}$

Essa impossibilidade de elaborar o passado tácito do testemunho da catástrofe nos é apresentada por Seligmann-Silva em "Zeugnis" e "Testimonio": um caso de intraduzibilidade entre conceitos quando contrapõe o testemunho da Shoah e o Testimonio na América Latina ao diferenciá-los por meio da necessidade de testemunhar em uma acepção mais religiosa ligada a punição do Deus para com o povo judeu, no caso da Shoah e da necessidade de testemunhar para fazer justiça, nesse sentido há necessidade de dar a voz ao "subalterno" para a criação de um herói exemplar. Ambos são sobreviventes, mas na Shoah temos o etos religioso tomando conta do discurso e no outro temos o etos jurídico. Nesse sentido, ambas as narrativas estão marcadas por essa acepção de denúncia e justiça, diante da ausência da voz dos sobreviventes da ditadura civil-militar brasileira. Além de realçar a inclinação heroica dos militantes entrevistados.

Pensamos, então, "o que difere essas duas narrativas fílmicas?". Podemos destacar as opções estéticas ali presentes: a primeira película, de Murat, foi construída sob o argumento de recuperar as vozes silenciadas de oito mulheres sobreviventes das prisões durante a repressão da ditadura civil-militar brasileira. Observamos que a diretora realizou uma seleção de narradoras que singraram por caminhos diversos, desde a escolha por viver em uma comunidade religiosa, passando por mulheres que encontraram na profissão sua fuga; chegando a

\footnotetext{
${ }^{20}$ SELIGMANN-SILVA, 2008, p. 66
} 
continuidade da luta política no trabalho comunitário. Todas perpassadas por um mesmo sentimento a necessidade de suportar as lembranças dolorosas da memória traumática. A diretora costura essas narrativas testemunhais com a encenação dos sofrimentos de uma personagem anônima na difícil tarefa de sobreviver, traçando uma crítica ao modelo social que, mesmo depois da ditadura, continua alijando a memória dos militantes com a mácula do terrorismo. Ao mesmo tempo, utiliza a voz da personagem anônima como a face da voz do narrador que procura assimilar os diversos narrares e as diversas conversas dessas narrativas, por isso dizemos que a personagem ficcional encenada por Irene Ravache, busca representar a síntese e a antítese daquelas narradoras. Vejamos o que relata a narradora anônima criada por Murat em QBTVVV:

Observando do lado de fora, como um voyeur olha pela janela da vizinha, meu olhar é igual ao de todo mundo. E a história de Maria hoje, uma educadora que é casada e tem dois filhos parece não ter muito a ver com esse passado. Na maternidade, Maria diz ter resgatado a possibilidade de vida, mas isto explica ou encerra tudo? ${ }^{21}$

Notemos que a narradora anônima de QBTVV, questiona a aparente sobrevivência de Maria mediada pela maternidade, para a narradora problematizar a opção de Maria em enterrar seu passado ao se perguntar se realmente o passado foi aniquilado pela memória ou se esta seria apenas uma forma de garantir a sua sobrevivência por meio da sobrevida conquistada com a maternidade. $O$ conflito se acentua no discurso da narradora quando se questiona "mas isso explica ou encerra tudo?". A narradora não acredita que a sobrevivência funda um fim para o sofrimento e a mácula deixada na alma daquelas mulheres, por isso, deixa evidente sua incredulidade diante da uma vida "normal" que buscam representar aquelas mulheres.

Em outra passagem do testemunho de Maria do Carmo, fica evidente a necessidade de apegar-se à maternidade como forma de garantir a sobrevivência em meio ao terror que cada sobrevivente passa a viver no que resta de suas vidas:

\footnotetext{
${ }^{21}$ QBTVV, 12'02" -12'36"
} 
eu descobri que esse tiro que eu dei neles era de saúde e me reconciliei com esta situação na minha primeira gravidez. Descobri que a melhor coisa do mundo era ser mulher. (...) E agente produz vida, uma coisa... Não é uma frase, nem um troço intelectualizado, foi uma descoberta tão bonita. Ai que eu descobri que ser mulher era o maior barato. ${ }^{22}$

Para a narradora de QBTVV há uma posição de afastamento em relação ao evento traumático, peculiar aos narradores testis, o que garante certa isenção para analisar o que se passa na narrativa do trauma, ao formalizar estratégias de sobrevivências que possam afastá-las cada vez mais de seu passado, seja para se proteger ou para proteger seus familiares. Assim narrar não seria mais fundamental? E sobreviver seria? Quando questionamos a relação entre narração e sobrevivência, observamos que a sobrevivência acaba se tornando sinônimo de esquecimento, como observamos no depoimento de Estela Bohadana:

Eu tenho um filho de 10 anos e um que vai fazer 15, mas o que eu sinto, nos dois, é que, embora o fato de eu ter sido presa, ter sido torturada, incomode, crie uma certa revolta, eles preferem que eu não fale. Quer dizer, eu sinto que é um assunto que incomoda tanto, que é melhor que se esqueça. Eu acho que eles de alguma forma reivindicam que eu esqueça, talvez para que eles mesmos não entrem em contato com uma coisa tão dolorosa. ${ }^{23}$

O que Estela Bohadana acirra em seu discurso é o conflito da duplicidade existente na construção do testemunho, uma vez que formaliza um testemunho, faz escolhas na difícil tarefa de lembrar e esquecer, já que a condição de sobrevivente de experiências traumáticas promove uma exasperação da dimensão do sofrimento, pois contraditoriamente necessita testemunhar, narrar o que aconteceu, mesmo tendo necessidade de esquecer partes dessa narrativa como forma de se proteger do horror que essas lembranças lhes causam.

Não há como alijar da sua existência tais experiências, ao mesmo tempo as lembranças são entrecortadas por vazios que $\circ$ próprio narrador/personagem/testemunho não consegue explicar. Observamos assim,

\footnotetext{
${ }^{22}$ QBTVV, 10'23" - 12'00"

${ }^{23}$ QBTVV, 20'21" - 20'56"
} 
que o narrador/personagem/testemunho passa a compreender que construiu uma identidade nova, tão marcante quanto à antiga, de combatente, que representa não mais aquele passado, e sim um misto de suas lembranças e a necessidade de suportar as consequências terriveis e inesquecíveis daquele passado, que até hoje estão presentes. Seligmann-Silva afirma que esta necessidade de testemunhar faz referência a chave do trauma, a uma necessidade de justiça e de dar conta da exemplaridade do herói e de conquistar uma voz, silenciada e oprimida, no caso de Estela.

Também em torno da heroicização dos militantes, o filme de Renato Tapajós e Tony Ventura utiliza outra estratégia cinematográfica, tenta mostrar que a luta contra a ditadura militar se desdobrou na busca, no presente de um lugar na sociedade, que verbere sua proposição resistente. Nesse sentido as quatro pessoas que fazem parte do documentário de Tapajós e Venturi fomentam o imaginário de que "tudo vale a pena quando a alma não é pequena", como Dulce Maia parafraseia Fernando Pessoa em seu depoimento emocionado sobre sua condição resistente.

A narrativa de No olho do furacão, é formada pelo depoimento de dois homens e duas mulheres e busca apresentar um cenário militante da história e do cotidiano de heróis que sobreviveram à luta contra a ditadura no Brasil. Os diretores Tony Venturi e Renato Tapajós exploram caminhos diferentes na condução desse documentário, pois encontramos um comprometimento tamanho de Renato Tapajós com o projeto de recuperação do heroísmo dos militantes ao ponto de se incluir nas cenas, acompanhando os entrevistados como parte desses depoimentos; já que Renato também é um sobrevivente e hoje delega sua história ao compromisso de narrar cinematograficamente o valor das ações e dos homens e mulheres comprometidos com a luta contra a ditadura no Brasil. Por isso, antes de tudo, os diretores criam um efeito de comprometimento com aquelas histórias e sua função revolucionária na contemporaneidade. Com isso o filme busca revelar tipos diferentes de revolucionários: a) o que, após a abertura, recupera seus direitos civis e políticos e se volta à política partidária; b) o que 
continua na resistência, mas sob outro viés, uma resistência ligada à compaixão e ao trabalho voluntário; o revolucionário que sai de dentro do sistema repressivo e que, de certa forma, continua sua relação com o estado repressor como adestrador de cães da Polícia Militar do Estado de São Paulo. Histórias que os confinam e, ao mesmo tempo, completam suas existências, mas que associadas a isso representam a sobrevivência, não mais como derrota, mas como esperança de quem precisa trabalhar para mudar o mundo, seja na política, no trabalho voluntário ou na formação de um contingente não humano para lutar pela ordem social.

O passado heroico dos militantes é descrito com detalhes, mostrando, entre outras coisas, as dificuldades vivenciadas por eles durante a resistência e o compromisso daqueles homens e mulheres com o movimento, como no testemunho de Carlos Eugênio Paz (Clemente):

Não podia fazer nenhum barulho, porque oficialmente os dois companheiros que moravam na casa saíram para trabalhar (...) quando vinham de noite traziam sanduiche e coca-cola, coca-cola quente... aquela coca-cola que já veio do botequim gelada, mas até chegar em casa tava quente, e sanduíche de mortadela. Aquelas coisas barata [sic] que a gente podia comprar porque o dinheiro ali não era... O dinheiro custava sangue, né? Nosso. Nós era [sic] muito espartanos nessas coisas, a gente não gastava dinheiro, assim sabe, era uma coisa assim de princípio nossa, né? A gente não cuidava do bem estar da gente primeiro. ${ }^{24}$

O valor do dinheiro e a necessidade de valorizá-lo ficam latentes na passagem acima. O mesmo ocorre no testemunho de Robêni da Costa (Rosângela) que de certa forma aponta o quanto era necessário para manter a sobrevivência do movimento, os sacrifícios alimentares, pois como nos mostrou Clemente "o dinheiro custava sangue".

O dinheiro era muito curto, era só o dinheiro que vinha pra fazer a manutenção do aparelho e vinha da organização e era o Alcides que fazia a comida, ele cozinhava. E a comida era... contar não dá pra acreditar, mas era assim, era arroz , arroz que japonês gosta, que chama gohan, e era uma sardinha que a gente comprava no

\footnotetext{
${ }^{24}$ NOF, $14^{\prime} 06^{\prime \prime}-14^{\prime} 39^{\prime \prime}$
} 
mercado de Pinheiros, aquela sardinha seca salgada e ele punha pra perder um pouco de sal, depois fritava e agente comia aquilo, semanas e semanas. ${ }^{25}$

O filme é marcado por uma pesquisa de arquivo e traça dois momentos das vidas das personagens como se quisesse desnudar as facetas do terror e da sobrevivência, pois cada entrevistado será direcionado para discorrer sobre seus traumas e dores, de um lado; de outro, as alegrias e satisfações do cotidiano resistente durante suas experiências na luta contra a ditadura civil-militar pós1964 e sua rotina após a anistia. De certo modo, nesse estafe, os dois filmes projetam um caminho parecido, pois em QBTVV também temos a comparação de como foram as ações que as militantes participaram e como fizeram para manter seu engajamento ideológico após a anistia.

Essa luta contra a ditadura civil-militar brasileira construiu espaço para o testemunho e denúncia das atrocidades promovidas pela ditadura no Brasil, com mais liberdade após a anistia política. O que terá uma dupla função no cenário ditatorial, de um lado, permite que exilados políticos retornem para o Brasil, promovendo o perdão irrestrito dos crimes a eles atribuídos. De outro lado, garante a impunidade para com as atrocidades praticadas contra a sociedade em nome da Lei de Segurança Nacional e silencia toda e qualquer forma de denúncia contra o estado brasileiro, que abdicou de suas responsabilidades para com as torturas, os sequestros, os ocultamento e desaparecimento de corpos.

Como tratar da sobrevivência desses homens e mulheres diante da indignação pelo silenciamento promovido pela Anistia? Robêni, no início de NOF mostra um pouco do que seria a tônica da crítica no documentário. Diz ela: "os meus filhos me tiram sarro. Pô, mãe, você não cria juízo nunca? Então ... não consigo! Acho que o que sobrou é uma ... eu chamo de indignidade ... é indignação, por ver tanta coisa errada" ${ }^{26}$. Sentindo-se completamente digna pelas suas ações, a militante percebe a necessidade de resistir, inclusive à família que deseja que a mãe de família assuma um lugar mais passivo na sociedade e esqueça a indignação que

\footnotetext{
${ }^{25}$ NOF, 14'57' - 15'37'

${ }^{26}$ NOF, 02'47' - 03'11'
} 
um dia lhe levou à luta contra a ditadura e hoje lhe mantém na luta por dignidade humana.

A crítica reservada à Anistia se tornou pano de fundo nos filmes. Em Que bom te ver viva, Lucia Murat propõe um debate sobre a sobrevivência e a manutenção da dignidade feminina após experiências extremas de violência, dor e sofrimento, marcando seu território como um dos primeiros documentários realizados no Brasil com sobreviventes da ditadura após a abertura política. Já em No olho do furacão, temos também certa crítica de como a Anistia foi cruel para com os sobreviventes. Mesmo com o fim do regime civil-militar, os sobreviventes de certo modo foram impedidos de serem reconhecidos como testemunhas de luta e sobrevivência. Desse modo, não havia espaço para denúncia, pois a Anistia arregimentou uma grande operação borracha, em que nada deveria ser falado sobre os 21 anos de ditadura.

Ambos documentários foram dirigidos por testemunhas vivas da resistência, o que marca o compromisso desses autores com uma reescritura da história, como salienta Walter Benjamin ao descrever a necessidade de ler a história à contrapelo, desmascarando as versões da história cristalizadas pelo poder. $\mathrm{O}$ testemunho das mulheres, em ambos os documentários aqui analisados, foi marcado pela culpa diante da derrota e o desejo de desforra diante da crueldade de seus torturadores. Não que essa desforra pudesse ser compreendida como simples ressentimento, como avalia os defensores da ditadura, mas como clamor da sobrevivência, para as mulheres que fizeram seus testemunhos nos documentários tomamos a epígrafe do filme QBTVV: "a psicanálise explica porque se enlouquece, não porque se sobrevive" ${ }^{27}$. Do mesmo modo, a fala de abertura da personagem anônima criada por Murat em QBTVV, denota bem esse sentimento, para ela "tudo começa exatamente aqui, na falta de respostas. Acho que devia trocar a pergunta ao invés de porque sobrevivemos seria como sobrevivemos? ${ }^{28}$. Por isso para ela é necessário "aprender a conviver com a

\footnotetext{
${ }^{27}$ Bruno Bettelheim, QBTVV, 00'22"

${ }^{28}$ QBTVV, 00'49"'-01'01"
} 
certeza de que ter sobrevivido foi absolutamente casual”29.

Lúcia Murat foi presa e violentamente torturada no DOI-CODI, onde permaneceu durante dois meses e meio. O mesmo aconteceu com Renato Tapajós, que chegou a escrever um livro na prisão: Em câmera lenta, publicado após sua saída da prisão, como forma de resiliência de suas experiências na militância e na prisão. Mas foi por meio da linguagem cinematográfica que ambos abriram os arquivos dos sobreviventes e deram a eles o espaço necessário para que pudessem tirar do esquecimento o assassinato de seus entes queridos, seus relatos sobre o que foi a tortura e, sobretudo, como vivenciaram estes acontecimentos e sua dificuldade de lembrar e narrar, como demonstra Maria do Carmo:

O que é que foram aqueles 60 dias... é muito... parece que foram 60 anos, isso eu já disse, não dá pra descrever. É uma coisa terrível, porque... é uma luta constante para você se manter inteiro. Eu me lembro que eu estava menstruada. Eles, então, para me pendurar no pau-de-arara, em consideração em ser uma senhora, me punham uma calça nojenta. Uma calça de homem toda suja de tudo quanto era coisa. E eu ficava pendurada com aquela calça. Porque começou a pingar e eles disseram que não estavam a fim de ver aquele espetáculo puseram a calça. Ai de vez em quando eles me pegavam com a calça e tudo e me jogava [sic] dentro de um aquário que tinha ali numa outra sala, depois pegava [sic] e tornava[sic] a pendurar no pau-dearara. Isso durou até... eu não me lembro bem, é tudo muito confuso. Só me lembro que teve uma hora que... é... tavam tirando a minha pressão e o outro sujeito dizia assim: "pode continuar, pressão de atleta, pode continuar!" ${ }^{30}$

O depoimento de Maria do Carmo no filme de Lúcia Murat retrata e reconstrói artisticamente a memória dos oprimidos durante a ditadura civil-militar brasileira pós-64. A diretora do filme seleciona aquilo que deseja discutir e compartilhar com o espectador. Essa seleção alimenta o debate relativo ao conflito ficção/realidade proposto pelo cinema documentário. Deste modo, observamos que a estratégia de construção narrativa entrelaçada ao testemunho amplifica ainda mais os liames entre o ficcional e o real. Essa costura entre a realidade e a

\footnotetext{
${ }^{29}$ QBTVV, 62'00 - 62'05"

${ }^{30}$ QBTVV, 12'38' - 13'46"
} 
ficção dá ao leitor a tarefa de separar ou não a realidade da ficcionalidade. Assim como afirma Marialva Barbosa:

\footnotetext{
Se o passado for visualizado como algo que pode ser recuperado, as fontes, documentos e emblemas do passado que chegaram até o presente, sob forma de rastros, serão privilegiados na interpretação. Se por outro lado, considera-se que o que chega do passado são vestígios memoráveis, permanentemente reatualizados pelas perguntas que do presente são lançadas ao pretérito, o que será destacado é a capacidade de invenção da narrativa. Ou seja, não se pode eliminar a categoria interpretação da história, da mesma forma que a história será sempre uma narrativa. $^{31}$
}

Os filmes documentários que estamos analisando aqui possuem essa potência de interpretar a história da sobrevivência dos militantes que lutaram para destituir a ditadura brasileira e trazem consigo os vestígios desse passado, que aos poucos vai sendo trazido ao presente. Quando essas narrativas vem à tona há, consequentemente, uma atualização dessa história, pois novos olhares, novas vozes, novas interpretações são lançadas para o leitor/espectador. Desse modo o espectador trava um debate com a obra, busca resignificar suas impressões sobre o passado e constrói postulações antes impensáveis, por isso fica evidente a relação performática entre a obra cinematográfica, os autores (personagens, entrevistados, diretores) e os leitores, recuperando as premissas de Pierce, Morris e Iser $^{32}$ no campo de uma semiótica do objeto e da interpretação; ou de Jauss quando analisa a relação entre a obra e o leitor, pois, para ele,

A relação entre literatura e leitor pode atualizar-se tanto na esfera sensorial, como pressão para percepção estética, quanto também na esfera ética, como desafio a reflexão moral. A nova obra literária é recebida e julgada tanto em seu contraste com o pano de fundo por outras formas artísticas quanto contra o pano de fundo da experiência cotidiana de vida. ${ }^{33}$

A atualização do leitor/espectador será fundamental no contato com os filmes em questão, pois ao assistir QBTVV e NOF percebemos a presença ideológica

\footnotetext{
${ }^{31}$ BARBOSA, 2007, p.17

32 Ver CAMPOS, 2011, 57-58.

33 JAUSS, 1994, p. 53
} 
dos autores como aqueles que constroem a narrativa, aparecendo ou não no filme. No filme de Lúcia Murat, sua presença é marcada pela voz da narradora e pela presença da personagem fictícia. No caso de NOF, temos Renato Tapajós imerso no cotidiano dos entrevistados, mostrando-se partícipe daquelas memórias. Os diretores/autores, ao escolherem os fragmentos que serão apresentados ao espectador, alteram o estado pacífico do leitor, impondo-lhe uma necessidade de reflexão sobre tais testemunhos. As ações performáticas desses narradores/personagens/testemunhos, tanto no filme de Murat quanto no filme de Renato Tapajós, expressam em suas narrativas "segredos" revelados de um passado difícil e passível de ser superado, mas que as câmeras, e todo aparato técnico que requer uma filmagem, pressupõem uma observação de si, fazendo com que a narração seja anteriormente pensada para que diante da câmera e do diretor seja dado seu depoimento. Desse modo, torna-se relevante a proposição de Marialva Barbosa ao considerar que:

Performar é realizar uma ação artística no tempo e no espaço. Porém, não é só a qualidade efêmera de seus atos que a caracteriza e sim a emergência de um ato criativo como articulador de processos estéticos, humanos e/ ou sociais em momento presente. ${ }^{34}$

A performance enquanto ação está presente na atuação da atriz, que interpreta a personagem anônima, voz que não cala, fala direto para câmera que filma, dialoga diretamente com o espectador, incluindo-o em sua participação performática. No caso de QBYVV, cada uma das oito mulheres, em detrimento da personagem ficcional, tem dificuldade de encarar a câmera e contar suas dores. A personagem anônima não narra somente, convida o espectador a fazer parte da ação reflexiva e interativa durante a ação cênica que envolve o documentário, mesmo quando o cerne do debate seja a necessidade de narrar contrastando com a urgência de esquecer. Nesse caminho o conceito de performance está atrelado a condição de narradoras/personagens/testemunhas, que por nós pode ser entendida como nos apresenta Jorge Glusberg (2005, p. 65) ao defender, em $A$

\footnotetext{
${ }^{34}$ BARBOSA, 2007, p. 1
} 
arte da performance, que a performance "é fonte de numerosos fantasmas psicológicos que tocam a interioridade do sujeito e põem em crise sua estabilidade; estabilidade - literalmente falando - que se fundamenta na repetição normalizada de convenções gestuais e comportamentais". Tais repetições de gestos e comportamentos são identificáveis em vários desses depoimentos, o que gera uma instabilidade, levando as testemunhas a calar-se, a chorar, a ficarem perplexas, diante da insuportabilidade das situações. Essa instabilidade também pode ser identificada em Renato Cohen, quando considera que a "performance é basicamente uma arte de intervenção, modificadora, que visa causar uma transformação no receptor"35. Como aponta Paul Zumthor, "a performance e o conhecimento daquilo que se transmite estão ligados naquilo que a natureza da performance afeta o que é conhecido. A performance, de qualquer jeito, modifica o conhecimento. Ela não é simplesmente um meio de comunicação: comunicando, ela o marca" ${ }^{\text {"36 }}$. Vejamos como isso se dá no testemunho de Maria Luiza (Pupi):

Quando eu fiquei grávida e aí eu tava até fazendo terapia... e aí... o terapeuta disse "agora eu acho que você já está bem, vai embora pra casa, vai ter seu filho, vai criar seu filho.". Porque é uma vida nova que surge, é uma esperança grande que vem junto. E aí você se desloca do social para o individual e aí vai viver uma outra coisa. ${ }^{37}$

Quando Pupi relata a conversa com o terapeuta, deixa evidente a mágoa que sente quando lembra da cena, pois ela queria convencê-la de que era preciso esquecer todo o seu passado e que o filho teria que ter uma outra vida, longe de suas memórias. Mas isso seria possível? Como poderia ela passar uma borracha sobre suas memórias? O incômodo de Pupi, sem dúvida, espelha o incômodo do espectador, pois como seria possível dizer para um sobrevivente "Esquece tudo! vai viver uma nova vida!"?

Impossível, pois as paixões e o pensamento ideológico formaram as bases do

\footnotetext{
${ }^{35}$ COHEN, 2002, p. 45-46

${ }^{36}$ ZUMTHOR, 2007, p.32

${ }^{37}$ QBTVV, 33'30" - 34'01'”
} 
envolvimento com a situação política do país por parte desses militantes. O desejo de revolucionar, viver na clandestinidade e, se fosse necessário, matar, estava pungente, pois era preciso viver no limiar entre a vida e a morte, pois tinham a certeza de estar promovendo um bem para a humanidade e para eles mesmos, já que lutavam contra o mal avassalador, representado pela ditadura civil-militar. Mas aos sobrevivente restaram as máculas deixadas pelo insucesso da revolução, deixando marcas perceptíveis em todos os depoimentos. Os traumas amargados pela lembrança dos que morreram e a incompreensível sensação de que a sociedade não sabe ou faz questão de não saber o quão foi importante ser um militante e o quanto era necessário reconhecer os verdadeiros heróis da nação. Vejamos o depoimento de Carlos Eugenio Paz em NOF sobre a morte de Carlos Marighela:

Eu demorei muito anos para parar de chorar a morte. Talvez é por causa disso que eu diga a você, que eu cheguei quase a perder a ternura. Porque teve uma hora que eu parei de chorar. Mas nessa época agente chorava os nossos mortos ainda. Foi... Chorei em casa, chorei na rua. Fiquei desesperado por que eu andava pela rua e saí para encontrar o pessoal da organização. E andando ali por Copacabana, e aquilo... Puxa! Mas não tem uma bandeira a meio pau. A população continua andando... quer dizer... a vida está exatamente igual... Quer dizer, morreu, assim, o brasileiro mais importante para esse país, para o destino desse país... e tudo continua igual! $!^{38}$

Sem dúvida, o sofrimento em relação aos mortos deixou máculas, que duraram muito tempo a ponto, no caso de Marighela, que a história delegou a sua memória ao ostracismo; pois na conjuntura de nossa sociedade contemporânea, poucos sabem quem ele foi ou o que representou para a história política nacional. $\mathrm{O}$ mesmo acontece com inúmeros militantes que foram esquecidos, ou melhor, nem são reconhecidos como parte da história brasileira, pois foram rotulados de terroristas e criminosos. Os filmes que analisamos buscam reconstituir as histórias desses militantes e descontruir a imagem negativa que ainda hoje paira sobre os sobreviventes da ditadura civil-militar brasileira.

Essas histórias de vida são, ao mesmo tempo, histórias marcadas por

\footnotetext{
${ }^{38}$ NOF, 34' 32" - 35'06"
} 
experiências limites, pois os militantes não foram somente presos e interrogados, como deveria ser a prática do estado que busca investigar o que eles chamavam de terrorismo. Aqueles revolucionários foram submetidos a intensas torturas, o que modificou bastante o sentido da palavra sobreviver, pois nela está a convivência com o trauma e com o sofrimento, que passa a ser uma presença recorrente, um conflito entre o sobrevivente de hoje e memória do jovem combatente, que no passado foi aquele quem lutou e perdeu! Humilhações imponderáveis da tortura que não se pode esquecer. Lúcia Murat em QBTVV, disponibiliza a imagem deste conflito no depoimento da mãe de Maria do Carmo numa perspectiva, enfim "positiva", de que no final a filha supera o insuperável:

No principio a vida dela foi muito difícil, ela tinha pesadelos incríveis, alucinações, sofreu muito... O médico do Chile chegou a me dizer que se ela houvesse perdido uma mão, um dedo, seria fácil, porque a gente veria o problema, mas não. O que ela perdeu foram células cerebrais, isso dificultou muito no princípio e para a vida dela. Felizmente ela superou tudo isso e hoje ela educa muito bem os seus filhos e, sobretudo, ela guarda uma grande coerência de vida. ${ }^{39}$

Havia na maioria dos relatos apresentados a experiência da mudança de nome, uma nova identidade construída para ser militante. Robêni da Costa se tornou Rosângela, Carlos Eugênio virou Clemente. Identidades que estabeleceram outros padrões de comportamento, de clandestinos no próprio país, sem referência de amigos ou família, cumprindo ordens, sem divulgar endereço. Mas como todo jovem, estudava, trabalhava e namorava. Esse comportamento natural da juventude foi um caminho destacado por Tapajós e Venturi, para combater os contínuos discursos corrosivos de terroristas, que assombravam seus cotidianos. Eles viveram intensamente! Talvez este seja um aspecto relevante no filme de Renato Tapajós: o de que os entrevistados se apresentam fora do estereótipo de brutalidade e falta de alegria. Eles se apresentam como estudantes e trabalhadores preocupados com o próximo, sonhando com o futuro que teriam preferencialmente em uma sociedade melhor. E isto se observa no relato de

\footnotetext{
${ }^{39}$ QBTVV, 14'13" - 14'49"
} 
Carlos Eugênio:

A gente entrava num carro.. bicho, era piada, era brincadeira entendeu? Era um clima de camaradagem total, total... completamente fraterna. A gente na reunião, num aparelho assim, a gente fazia verdadeiras festas, com macarrão com sardinha, vivia no dia-a-dia da cidade e da rua, entrando no botequim ali, saber onde que é não-seio-quê. Sabe? Vivia.. não era uma coisa assim... não vivia completamente escondido. Agora a minha casa ninguém sabia onde era, só eu e minha mulher. E se eu tava morando sozinho só eu é que sabia. ${ }^{40}$

A condição resistente vivida pelos entrevistados fica marcada em No Olho do Furacão como um cotidiano que se aproxima ao dos demais jovens, mas possuíam particularidades pouco entendíveis quando não se está vivendo sob um regime de exceção, como foi a ditadura civil-militar brasileira. Vejamos o exemplo apresentado por Clemente sobre as relações afetivas entre os membros do grupo:

Mas tinha tudo isso, tinha amor, tinha ódio, tinha relação mal resolvida, tinha relação bem resolvida, tinha... tinha gestos tão incríveis, mas tão incríveis. Você aí imaginou e aí toca um pouco naquela.. no começo da história da revolução sexual e do amor livre, aquela coisa toda, né?... Tinha momentos em que... teve momentos em que,...Teve um caso concreto que eu conheço. de uma companheira que tava morando com o companheiro, apaixonado por um companheiro que. de repente, o companheiro quis acabar a relação, então tavam [sic] no mesmo aparelho e disse que estava querendo acabar porque estava apaixonado por outra companheira, entendeu? E de repente essa companheira chegar e dizer assim "poxa, traz ela pra cá.”. E essa companheira ir pra lá e a outra companheira ceder a cama pros dois dormirem juntos e fazerem amor." 41

A relação aberta proposta na militância lembra bastante o cenário de companheirismo das comunidades alternativas de hippies, que de certa maneira reforçam o desejo utópico dos jovens de construir um mundo melhor, onde as questões amorosas bem demarcadas pelos princípios do casamento burguês pudessem sem substituídas pelos princípios do amor livre, mais próximos do pensamento socialista que pautava os movimentos de resistência. $O$ filme de

\footnotetext{
${ }^{40}$ NOF, 21'46" - 22'16"

${ }^{41}$ NOF, 22'17' - 23'14"
} 
Renato Tapajós e Tony Venturi salienta que a juventude que se envolveu nos movimentos de resistência não representa a inconsequência ou a ingenuidade. Pelo contrário: encontramos profunda maturidade, pois vale a pena manter os laços de companheirismo e não os sentimentos de posse. A revolução é mais importante que as vidas individuais, por isso, para os diretores, não seria cabível conceber que o amor durante a revolução poderia ser o responsável pela derrocada do movimento, como apregoam filmes como $O$ que é isso companheiro, justificando que a imprudência dos jovens amantes seria o erro na luta armada.

O amor propalado pelo movimento de resistência gera seus filhos, mas nem sempre isso se dá de maneira natural, principalmente porque as mulheres são costumeiramente desmoralizadas em sua alma. Pelo fato de serem mulheres, as torturas não são abrandadas, pelo contrário, como denuncia Dulce Maia:

Eu fui a primeira mulher a ser presa no Brasil desse período, desse período sim.. e fui muito maltratada justamente por isso, por eu ser mulher, por eu ser de uma classe social diferente. Como? Eu era uma traidora para eles, eles me trataram assim, exatamente assim, eles diziam isso. Na época também havia todo um ódio assim uma coisa te... violenta contra um que era muito meu amigo e até hoje muito meu amigo: Chico Buarque... Vandré que também era muito amigo. Então eles queriam muito saber sobre eles. Eu vinha do Teatro Oficina, que tinha acabado de montar o Rei da Vela - Caetano, Gil também - o tropicalismo todo nasceu ali naquele momento. Eu era pra eles [a polícia] considerada uma estudante, mesmo eu não sendo uma estudante, porque eles tinham muito ódio aos estudantes também, então eles achavam inclusive que eu pertencendo a uma outra classe eu devia estar ligada aos estudantes e nunca deveria estar ligada a sargentos, a cabos, e.... Mas a traição minha era uma traição de classe, muito maior... ${ }^{42}$

Quando Dulce afirma ter sido a primeira mulher a sofrer tortura no Brasil, ela passa a representar não uma exceção, mas a norma. A mulher era vista pela repressão como "presas mais fáceis (...) eles se sentiam muito ofendidos na sua arrogância machista pelo fato daquelas mulheres terem coragem e dignidade de

${ }^{42}$ NOF, 44'09'- 45'27'" 
enfrentá-los" ${ }^{43}$, destaca Leane Ferreira de Almeida, em seu testemunho para o Intolerência e Resistência: testemunho da repressão política no Brasil (1964-1985). A dura situação feminina diante da repressão será matéria de denúncia e de revolta, pois vários filhos da resistência nem chegaram a nascer por conta das condições aviltantes delegadas àquelas mulheres, seja por conta dos seviços sexuais, seja pelo teor da violência, seja pelo simples prazer de subalternizar a mulher, especialmente quando elas estavam grávidas ou menstruadas. Várias delas trazem em suas memórias inúmeras situações de companheiras que, grávidas, abortaram em sessões de tortura, chegando à morte. Ou mesmo quando há a sobrevivência da mulher, como acontece com Regina Toscano, o único amparo é provar que continuará resistindo fora do cárcere, no intuito de ser mãe.

Quando fui presa tava grávida e perdi esse nenê que seria o meu primeiro filho lá. Durante a cadeia toda, o que realmente me segurou era a vontade de ter um filho, era a certeza que eu ia ter um filho. Isso representava para mim vida. Se eles tavam querendo me matar, eu tinha que dar uma resposta de vida. E ter um filho simbolizava, e simboliza até hoje, a resposta, que a coisa continua, que a vida está aí, que as coisas não acabam. ${ }^{44}$

O documentário de Lúcia Murat não foi feito com o objetivo de divulgar os casos de abuso, ou mostrar o quanto a maternidade é a grande responsável pela sobrevivência feminina, mas fica claro que esses dois pontos são representativos para compreendermos o outro lado da sobrevivência. Por conta disso, a diretora do filme nos questiona sobre a possibilidade de uma pessoa torturada ter condições de restabelecer algum pertencimento ao meio social e superar seus traumas, por fim, fazer a resiliência. Acreditamos que não só em QBTVV, mas também em NOF, ficou claro que é possível a resiliência existir, mas não possibilidade de memória e não como estratégia de esquecimento.

Desse modo, encontramos nos documentários certa urgência em mostrar que

\footnotetext{
${ }^{43}$ TELES; RIDENTE; IOKOI, 2010, p, 352

${ }^{44}$ QBTVV, 38'39" - 39'14"
} 
existe uma necessidade de nos identificar com este meio, para assim fazermos parte dessas narrativas, não como testemunhas, mas como testemunhantes, ou seja, expectadores que possibilitam que aqueles testemunhos sejam ouvidos e legitimados, em um exercício de performance, que faz com que o narrador/personagem/testemunho sinta-se à vontade para narrar, porque sabe que do outro lado há pessoas que se importam com seus testemunhos e thes ouvirão. Assim é possível sobreviver aos traumas, mesmo quando estamos em uma sociedade que cobra o esquecimento.

As obras artísticas produziram ao longo da história da humanidade representações, indagações e questionamentos imbuídos de ética e estética em que, ao mesmo tempo em que as condições emocionais e afetivas do espectador são acessadas, o seu comprometimento lógico-racional também o é. Os filmes Que bom ver viva e No olho do Furacão impelem atributos de narrativa artística de qualidade que se aproximam dos memoriais e da performance efêmera e insubstituível no tempo e no espaço. Mesmo que os filmes se constituam de fragmentos de vida real ou espelhamento do real, vimos ao longo desta análise, que podemos considerar tais documentários, obras autorais e singulares, pelo profunda imersão na representação da realidade e pelo sentido revisionista da figura do herói que as obras adquirem. Sem dúvida, cada um dos documentários aqui comentados traz o recurso da mobilização da participação do espectador, para uma negação da tortura e da violência contra a liberdade do pensamento humano. Por isso, tais filmes são exemplares da sobrevivência do relato de narradores/personagens/testemunhos de quem um dia esteve imerso no olho do furacão. 


\section{Referências Bibliográficas}

BARBOSA, Marialva. Vestígio do tempo: história cultural da imprensa brasileira e práticas sociais de leitura. Lisboa: Revista Portuguesa de História do Livro, 2007.

CAMPOS, Haroldo. Da transcriação: poética e semiótica da criação tradutora. Belo Horizonte: FALE/UFMG/Viva Voz, 2011.

COHEN, Renato. Performance como linguagem: criação de um tempo espaço de experimentação. São Paulo: Perspectiva, 2002.

CORNELSEN, Élcio Loureiro. O testemunho na chave do trauma: aspectos teóricos. In: UMBACH, Rosani Ketzer; CALEGARI, Lizandro Carlos (Orgs.). Estética e política na produção cultural: as memórias da repressão. Santa Maria - RS: editora UFMS, 2011.

CYRULNIK , Boris. O murmúrio dos fantasmas. São Paulo: Martins Fontes, 2005, p. 41

DE MARCO, Valéria. Literatura de testemunho e violência de estado. Revista LUA NOVA N ${ }^{\circ} 62,2004$.

DIDI-HUBERMAN, Georges. A imagem sobrevivente: histórias da arte e tempo dos fantasmas segundo Aby Warburg. Tradução: Vera Ribeiro. Rio de Janeiro: Contraponto, 2013.

GLUSBERG, Jorge. A arte da performance. Tradução: Renato Cohen. São Paulo: Perspectiva, 2005.

JAUSS, Hans Robert. A história da literatura como provocação à teoria literária. Trad. Sérgio Tellaroli. São Paulo Ática, 1994.

LEVI, Primo. É isto um homem? Tradução: Luigi Del Re. Rio de Janeiro: Rocco, 1988.

RICOEUR, Paul. Tempo e Narrativa. Tomo II, Trad. Marina Appenzeller. CampinasSP: Papirus, 1995.

SARLO, Beatriz. Tempo passado: cultura da memória e guinada subjetiva. Tradução: Rosa Freire D'Aguiar - São Paulo: Companhia das Letras; Belo Horizonte: UFMG, 2007

SELIGMANN-SILVA, Márcio. Zeugnis e Testemonio: um caso de intraduzibilidade entre conceitos. Revista Letras. $\mathrm{N}^{\circ}$ 22. Jun/Jan 2001. Disponível em: 
http://w3.ufsm.br/revistaletras/artigos_r22/ 11_marcio_silva.pdf. acesso em 20/08/2009.

SELIGMANN-SILVA, Márcio. Narrar o trauma: a questão dos testemunhos de catástrofes históricas. Revista Psic. Clin., Rio de Janeiro, Vol. 20, № 01, p. 65-82, 2008.

SOARES, Sérgio José Puccini. Documentário e Roteiro de Cinema; da préprodução à pós-produção. Tese de Doutorado. Campinas, SP: UNICAMP/IA, 2007.

TELES, Janaina de Almeida; RIDENTI, Marcelo; IOKÓI, Zilda Márcia Grícoli. Intolerância e resistência: testemunhos da repressão política no Brasil (19641985). São Paulo: FFLCH/USP, 2010.

ZUMTHOR, Paul. Performance, recepção, leitura. Trad. Jerusa Pires Ferreira, Suely Feneruch. $2^{a}$ edição. São Paulo: Cosac Naify, 2007.

\section{Filmografia}

MURAT, Lúcia. Que bom te ver viva. Documentário, 100 min. Cores. Brasil, Taiga, 1989.

TAPAJÓS, Renato \& VENTURI, Tony. No olho do furacão. Documentário. 56 min. Cores. Brasil, Olhar Imaginário, 2003. 